\title{
Generating meaningful conversation: World Café in strategic interprofessional planning in Continuing Education
}

\author{
Gerando conversas significativas: World Café no planejamento estratégico interprofissional em Educação Permanente
}

Generando conversaciones significativas: World Café en el planeamiento estratégico interprofesional en Educación Permanente

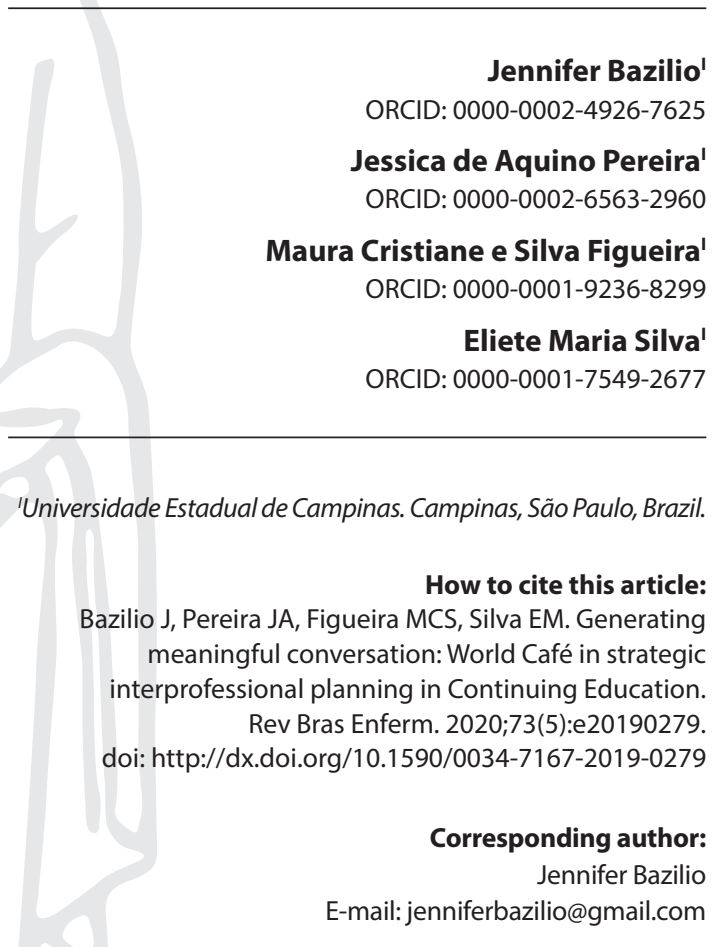

EDITOR IN CHIEF: Antonio José de Almeida Filho ASSOCIATE EDITOR: Fátima Helena Espírito Santo

Submission: 07-06-2019 Approval: 11-25-2019

\section{ABSTRACT}

Objectives: to present the particularities of the World Café, identifying the main aspects that characterize a planning strategy for a constructive, interactive, and participative dialogue of the individuals, aiming at collaborative and innovative learning. Methods: a World Café method workshop with 24 professionals from the teams that work in basic health units. Results: we obtained three analysis categories: Individual Needs, Group Needs, and Institutional Needs, which resulted in the Municipal Plan of Actions on Continuing Health Education. Conclusions: we found that the World Café was adequate and relevant for the discussion of key themes, for the practices of teams in Primary Care and the production and organization of data in a collective space. Final Considerations: the method can contribute to the construction of knowledge and proximity to the daily reality of interdisciplinary teams, as well as serving as a tool in the preparation of planning in Permanent Education.

Descriptors: Methodology; Qualitative Research; Primary Health Care; Continuing Education; Intersectoral Collaboration.

\section{RESUMO}

Objetivos: apresentar as particularidades do World Café identificando os principais aspectos que caracterizam uma estratégia de planejamento para um diálogo construtivo, interativo e participativo dos sujeitos, com vistas ao aprendizado colaborativo e inovador. Métodos: realizou-se uma oficina de trabalho com o método World Café, com 24 profissionais das equipes que atuam em unidades básicas de saúde. Resultados: foram obtidas três categorias de análise: Necessidades Individuais, Necessidades Grupais e Necessidades Institucionais, que resultaram no Plano Municipal de Ações em Educação Permanente em Saúde. Conclusões: verificou-se que o World Café foi adequado e relevante para a discussão de temas balizadores, para as práticas das equipes na Atenção Primária e para produção e organização de dados em espaço coletivo. Considerações Finais: o método pode contribuir para construção do conhecimento e aproximação à realidade cotidiana das equipes interdisciplinares, bem como servir de ferramenta na elaboração do planejamento em Educação Permanente. Descritores: Metodologia; Pesquisa Qualitativa; Atenção Primária à Saúde; Educação Continuada; Colaboração Intersetorial.

\section{RESUMEN}

Objetivos: presentar las particularidades del World Café identificando los principales aspectos que caracterizan una estrategia de planeamiento para un diálogo constructivo, interactivo y participativo de los sujetos, con vistas al aprendizaje colaborativo e innovador. Métodos: ha sido realizado un taller de trabajo con el método World Café, con 24 profesionales de los equipos que actúan en unidades básicas de salud. Resultados: han sido obtenidas tres categorías de análisis: Necesidades Individuales, Necesidades Grupales y Necesidades Institucionales, que resultaron en el Plan Municipal de Acciones en Educación Permanente en Salud. Conclusiones: ha sido verificado que el World Café ha sido adecuado y relevante para la discusión de temas motivadores, para las prácticas de los equipos en la Atención Primaria y para producción y organización de datos en espacio colectivo. Consideraciones Finales: el método puede contribuir para la construcción del conocimiento y acercamiento a la realidad cotidiana de los equipos interdisciplinarios, bien como servir de herramienta en la elaboración del planeamiento en Educación Permanente.

Descriptores: Metodología; Investigación Cualitativa; Atención Primaria a la Salud; Educación Continuada; Colaboración Intersectorial. 


\section{INTRODUCTION}

Among the forces that corroborate the strengthening of the Single Health System (Sistema Único de Saúde-SUS) and the improvement of the quality of care, there is the training and qualification of its workers. Thus, the Ministério da Saúde (Health Department) has been encouraging actions that promote good practices in this field, especially in interdisciplinary work and in continuing education (CE). The $C E$ assumes meaningful learning, which can intervene in the local, institutional, and personal reality of people and work. It incorporates the active participation of workers, managers, and popular participation in their actions in both execution and planning ${ }^{(1-2)}$.

CE professionals, often known as facilitators, can be from any categories of health education, with technical knowledge, willingness, and affinity for active learning methodologies. They have the challenge of integrating the individual interest of the various professional categories into collective goals and promoting ways for these professionals to be able to work together and truly work in an interdisciplinary manner. In order to assist them in their actions, avoiding their loss during common emergencies in the work context, action planning is necessary.

In this context, the Permanent Education Health Plan is a systematized document comprising pedagogical information and policies that allow the optimization of work processes, such as planning, implantation, implementation, monitoring and evaluation of actions ${ }^{(1)}$.

Planning health actions is an essential step for the entire team so that each member participates and takes a proactive role in the actions and construction of the plan. The act of planning is inherent in the human nature essence because the action of thinking constitutes it before acting ${ }^{(2)}$. For its construction, the union between "reality" and the diagnosis of certain situations is necessary.

The "reality" depends on the interpretation of each being in a given context. The diagnosis of this context represents reality regardless of the viewer's perspective. The concept of situational diagnosis seeks to incorporate, within the possibilities, all dimensions of human action, as each social actor experiences reality differently from the reality of another being ${ }^{(2)}$.

For agreement among the different actors to occur, it is necessary a meeting that promotes encouraging dialogues, knowledge sharing, and opportunities for action in specific situations. This knowledge is aligned to the common good, remembering that each actor is situated, and therefore is interested in different aspects of the "common good," which requires negotiation (2). From these negotiations and consensus building, we built the Situational Strategic Planning.

Thinking about including the workers` view in the planning, without departing from the one proposed in the literature, respecting the feelings and experiments regarding the training needs, the most appropriate way possible would be to use a qualitative method that allowed the free expression of thoughts, without losing the critical reflection. Also, common interests would be united among professionals of different categories, leading them to collective thinking about the needs of the service as a whole.

A recent method used to exploit these skills and competencies is World Café (WC), as it allows team members to use logical thinking and focus both on adopting new perspectives to maximize the effects of debate and ultimately on sharing collective discoveries.
The discussion is based on questions, encouraging members to share their perspectives, and listening to others to discover the context and the problem from multiple perspectives. Thus, participants plan group activities based on collective intelligence ${ }^{(3)}$.

WC was born in 1995 as an initiative of a group of academics and business leaders interested in facilitating discussions between different social groups, resulting in a strategic and transformative social innovation that has spread around the world ${ }^{(3)}$. Since then, the WC has changed the scope and depth of the dialogues. Several experiences have proven successful in different areas, including health care, with dialogues for classifying drug curves, adolescent pregnancy prevention projects, nursing courses planning, and sector planning ${ }^{(4-7)}$.

It is a process that generates meaningful conversations around essential points, works to resolve critical issues facing today's society, and makes the situational diagnosis. Through conversation stories, and images emerge, projected from assumptions that people have in their own creative intelligence. At the same time, the method focuses on disciplined research on collaborative intelligence, focused on the cross-pollination of knowledge, avoiding valuing only the point of view or reality of a particular individual in discussions, as occurs in the ones with more directive structures such as structured interviews and focal groups ${ }^{(8)}$.

The WC method points out seven principles in its design: context setting, creating a hospitable space, establishing important questions to be explored; encouraging everyone's contribution; connecting participant's diverse perspectives, collective listening to ideas and insights, and sharing ideas ${ }^{(4)}$.

The minimum number referred to by the creators of this method is 12 participants. For lower numbers, it is advisable to use other approaches such as focus groups or dialogue circles( ${ }^{(4)}$.

Its constitution contributes to the development of skills in communication, relationships, and strategic planning, as it enables intersectoral and interprofessional work, with collaborative actions around themes or issues. Thus, it actively explores its political and analytical context, favoring groups to propose improvements and innovations to be implemented ${ }^{(8-9)}$.

This experience took place in the context of the $C E$ service of a municipality in the metropolitan region of Campinas, SP, Brazil, which has nine basic health units.

\section{OBJECTIVES}

To present the particularities of the World Café, identifying the main aspects that characterize a planning strategy for a constructive, interactive, and participative dialogue of the individuals, aiming at collaborative and innovative learning.

\section{METHODS}

The Research Ethics Committee of the Universidade Estadual de Campinas (Unicamp-State University of Campinas) approved the development of the World Cafe. Ethical procedures were respected at all times of the research, being considered Resolution No. 466/2012 of the Conselho Nacional de Saúde (National Health Council), which subsidizes ethical issues for the development of research involving human subjects. Between preparation and 
execution, two months passed from June to August 2018. The idea of using the WC method came after the doctoral exchange, through contact with professionals from research groups in Portugal.

The consolidation of the idea came after the discussion of the feasibility of data collection. To follow the central philosophy of participatory research in its construction, it would be necessary that data collection could bring together professionals from different categories and that the result would meet everyone's needs, respecting different knowledge and in an integrated way.

Thus, we began planning how it would be possible to gather these professionals in a dynamic in which we would gather as many of them as possible at the same time and place, without compromising assistance and preserving the necessary technical concepts in theWC.

For this, support from the administration was necessary, which, after explaining the project and its objectives, understood that the application of the results obtained in this WC would be valuable and could return in actions to qualify the service itself.

At the beginning of the activities, we made open invitations to the professionals who were willing to participate. They should confirm their presence and attend the established place, date, and time.

This strategy was not effective because there were no confirmations. We redid the invitations, this time using the WhatsApp social network, posting the original invitation among the professional groups, from whom we got immediate responses. The managers collaborated directly by promoting the event, thus reinforcing the need for the attendance of representatives of all categories of workers in their contact groups.

We pointed out that the invitation contained the place, date, and time when the activity would take place. It clearly presented the need for one or more representatives from each professional category and the basic health units in which professionals would be the representatives should agree to it.

As for the location chosen, this was designed in conjunction with the management and was a comfortable, safe, bright, centrally located environment in the city and strategic for the movement of participants, as they would move from different workplaces. Therefore, the choice of place is of fundamental importance in the participants' adherence ${ }^{(4)}$.

The WC technique requires a welcoming environment ${ }^{(4)}$, which is close to a simple conversation between friends, such as a coffee or afternoon tea meeting. To achieve our goal, the room was set up with circularly arranged tables to facilitate the flow of conversations and to allow everyone to be within each other's field of vision. The tables were covered with tablecloths and stocked with pens, post-its, cardboards, and marker pens. A coffee table with light foods such as fruits and juices was placed on a specific table, so that participants could move to the table during discussions, to the sound of popular Brazilian songs.

Professionals from the following categories attended the activity: gynecologists, pediatricians, general practitioners, nurses, nursing technicians, nursing assistants, pharmacists, and administrative support. No nutritionist or social worker was present due to work problems that made it impossible to participate in the WC.

At the beginning of the activity, there was an explanation to the participants about how this would look, their objectives; then, they signed the Free and Informed Consent form. With the unanimous agreement of the participants, we started the activity.
Each participant stayed in a group and had to choose a host. This host would be responsible for transmitting the contents discussed in the group, in the collective discussion rounds. The hosts are the only fixed participants at the tables, responsible for the total dispersion of the content discussed, that is, they are responsible for sharing the content discussed plus the knowledge and ideas of the group they represent.

The hosts at the World Café are the table leaders who play the important role of facilitators. Their expected task is to hear the real meaning behind the different comments and then turn them into a discourse that will make sense to the participants to strike a balance between active participation and mutual reflection by everyone present ${ }^{(5)}$.

We totaled 24 participants distributed in five tables, four of which contained five participants, and a table, four participants. A starting question was carried out by the host and discussed by the participants for 20 minutes. After this time, participants switched tables and started a new discussion regarding the next question. The questions are of great importance because, if not well elaborated, they may deviate from the proposed primary objectives. The number of questions is also essential and should be around three to four. If there is a need to address more issues, further meetings can be scheduled, and time intervals between meetings should not discontinue the processes.

We used questions at three levels: the first, which addresses the individual need for training (which training would you like to participate in?); the second involves other team members (What $\backslash$ Which training do you consider to be comprehensive for all staff in your work?); and the third, more comprehensive and open (What Which training can impact the daily work?).

At the end of the discussion of each question, participants switched tables to answer the next question, leaving all the material produced in discussion to be complemented by the next group to sit in that place. The material produced can be presented in the form of a report, annotations, paintings, doodles, whatever the participants have used to express their ideas because all of this production is very rich in content, and it is used in the analysis.

The way to obtain final content depends on the purpose for which the material will be used and may take the form of a report that suggests its use in other modalities that need participatory construction, such as municipal conferences, workshops for Multiannual Planning, among others actions ${ }^{(5-9)}$.

By shifting tables at random, the groups mingled, and, after being welcomed by the host, they had five minutes to share the subjects discussed in the groups in which they were previously. These rounds went on like this until the end of the questions. At this moment, we held the last exchange, in which, in plenary, there was a summary of the subjects discussed. After the activity was over, the hosts received the product of the discussions.

The data contained in the final product of the WC were analyzed using the thematic or categorical analysis technique ${ }^{(10)}$, which is understood as a set of research techniques that allows the interpretation of the content of any class of documents so that it is possible to perform the analysis and understanding of the meanings contained. For the elaboration of the results, we performed the skimming readings in the foreground, coded the results for the thematic categories constitution, and interpreted the data. 


\section{Results and discussion: World Café and the Continuing Education Plan in Municipal Primary Care}

The participants were female, with a mean age of 43.6 (SD = 8.8) years, with ten years or more of Primary Health Care working experience. Regarding education, $75 \%$ had a college degree, such as Medicine, Nursing, Pharmacy, and Administration.

At the end of the WC and with the condensed gross product, we obtained a participant conversation, converted into 32 pages of written material for the analysis.

We grouped the material according to the tables where the hosts were, attributing to it the report format, and have arranged this content for analysis of thematic categories to understand the needs and meanings. Also, to directly link the professionals' local and global needs to the CE strategies.

After content analysis by frequency of appearances ${ }^{10)}$, it was possible to constitute the thematic categories, which were approached for structural construction of planning in $C E$, as follows: Individual Needs Category, Group Needs Category, and Institutional Needs Category, presented in Chart 1.

Participants widely approached nursing techniques when discussing it in the dimension of Individual Needs, mainly the complex and poorly performed procedures in Primary Care. In discussions with group focus, they also cited it, but without significant value, demonstrating that the method used pollinates individual ideas, making them more dissolute and less critical in a collective perspective. In the Group Needs dimension, the discussion was more in-depth and thematic. Participants sought a transformation of their personal needs into needs of group interest, defending either the professional category or the work team as a whole. The very perception of being a "representative of the community" broadened the eyes as an interdisciplinary team member.

In this field, the participants' concerns turned to collaborative care in health units, such as reception, crisis care, consultations, assistance to risk groups, health education, among others. Their concerns returned to the performance of their duties, to enable the harmony of daily and interprofessional work, as well as humanized, ethical, and welcoming work for the community.

The participants' perception of the need for more communityoriented CE actions, quality in outsourced services and flows between the levels of municipal health services were strongly represented in the analyzed contents, so that the Group Needs dimension was extrapolated moving to Institutional Needs. Such reflections present the professionals as collective beings, who build and belong to the institution. They are constituent members of society, not just a team or service.

In presenting the final product of the plenary discussions, the host of each table summarized the overall needs noted in the three dimensions discussed. At the beginning of the discussion, it was possible to observe that the themes presented in the plenary were complementary to the subjects previously

Chart 1 - Thematic Categories, Paulínia, São Paulo, Brazil, 2018

\begin{tabular}{|c|c|c|}
\hline Problematic & Strategy & Action \\
\hline \multicolumn{3}{|c|}{ Categories: Individual Needs } \\
\hline $\begin{array}{l}\text { - Few trained professionals } \\
\text { in vaccination, dressings, } \\
\text { and collections for tests. } \\
\text { - The less performed nursing } \\
\text { procedures are forgotten. }\end{array}$ & $\begin{array}{l}\text { Follow-up discussions and } \\
\text { opening for individual } \\
\text { referrals, on-demand care, and } \\
\text { workplace training. }\end{array}$ & $\begin{array}{l}\text { - Specific training in loco. } \\
\text { - Periodic and permanent training in loco. }\end{array}$ \\
\hline \multicolumn{3}{|c|}{ Categories: Institutional Needs } \\
\hline $\begin{array}{l}\text { - Professionals' poor } \\
\text { understanding of the need } \\
\text { for Prevention in Primary } \\
\text { Care. } \\
\text { - Professionals understand } \\
\text { the reception as a function } \\
\text { of the nurse. } \\
\text { - Need for humanization } \\
\text { in care. } \\
\text { - Ethics and hierarchical } \\
\text { posture. }\end{array}$ & $\begin{array}{l}\text { - Expanded discussions for the } \\
\text { entire team, with a central } \\
\text { focus on the National Policy of } \\
\text { Humanization. } \\
\text { - Resume basic concepts and } \\
\text { principles of Primary Care. } \\
\text { - Strengthen the actions of the } \\
\text { medical and nursing ethics } \\
\text { committees in the municipality } \\
\text { with the support of problem- } \\
\text { solving methodologies. }\end{array}$ & $\begin{array}{l}\text { - In loco reception training, guided by the National Humanization Policy. } \\
\text { - Training in emergency care, focusing on non-medical skills. } \\
\text { - Conduct an Ethics symposium with workshops in its course. }\end{array}$ \\
\hline \multicolumn{3}{|c|}{ Categories: Institutional Needs } \\
\hline $\begin{array}{l}\text { - Improve communication } \\
\text { with central } \\
\text { administration. } \\
\text { - Need training for support } \\
\text { services. } \\
\text { - Lack of professional } \\
\text { motivation. } \\
\text { - Discontinuity of services } \\
\text { in management } \\
\text { exchanges. }\end{array}$ & $\begin{array}{l}\text { - Strengthen flows between } \\
\text { central administration and } \\
\text { Health Units. } \\
\text { - Strengthen educational and } \\
\text { motivational initiatives. } \\
\text { - Support Multiannual Work } \\
\text { Plans. }\end{array}$ & $\begin{array}{l}\text { - Strengthen periodic team and management meetings. } \\
\text { - Support periodic team and management meetings to establish flows. } \\
\text { - Support in discussions and implementation of protocols. } \\
\text { - Conduct campaigns on waste recycling. } \\
\text { - Conduct workshops with outsourced services seeking to fit the Primary Care } \\
\text { - } \text { Incorspective. } \\
\text { - Conduct more Continuing Education Planning workshops. } \\
\text { - Strengthen the participation of professionals in the planning of actions and services. }\end{array}$ \\
\hline
\end{tabular}


discussed at the tables, demonstrating the consensus production among the teams.

As the teams were of different units and different professions, this consensus demonstrated one of the most important findings of this experience, the collective spirit, interprofessional and collaborative, sought since the beginning of the work, thus respecting the participatory and significant principles of CE.

It was reported by the participants that the technique brought professionals closer to the knowledge of the needs and difficulties faced at work in addition to favoring dialogue. At the end of the WC, they felt lighter and with the perception that the problem brought was no longer as complex as previously perceived.

Given these results, a CE action plan was elaborated - based on Situational Strategic Planning ${ }^{(2)}$ referring to the needs encompassed in all categories, which were closely linked to the issues discussed.

\section{Study Limitations}

We highlight, as a limitation of the study, the lack of robust theoretical references to support the execution of strategic planning using this method.

\section{Contributions to the nursing field}

The knowledge of new management strategies is of utmost importance in the search for daily problem solving of nurses in such functions. The method collaborates so that professionals from different areas can maintain a collective dialogue based on common goals, without the area of the formation being a barrier to interdisciplinary work.

\section{FINAL CONSIDERATIONS}

The WC method proved to be very effective in constructing the planning of joint CE actions between different basic and interprofessional health units. It met the needs of collective construction and effectively promoted knowledge exchange among participants, favoring collaborative work.

This initiative increased the adherence of health professionals to professional training processes in the workplace, as they participated from the planning to the implementation of actions in CE. Also, the real need identified, experienced, and organized by these professionals, with the support of this method, framed it.

\section{REFERENCES}

1. Ministério da Saúde (BR). Secretaria-Executiva. Subsecretaria de Assuntos Administrativos. Educação Permanente em Saúde: um movimento instituinte de novas práticas no Ministério da Saúde: Agenda 2014 [Internet]. 2014 [cited 2019 Jan 23]. Available from: http://bvsms.saude. gov.br/bvs/publicacoes/educacao_permanente_saude_movimento_instituinte.pdf

2. Matus C. Política, Planejamento \& Governo. Tomo I. 2. ed. Brasília: IPEA, 1998.

3. Dawkins V, Solomon A. Introducing the world café to doctor of nursing practice students. J Nurs Educ. 2017;56(10):638-39. doi: 10.3928/01484834-20170918-11

4. The World Café Community. Café to go! A quick reference guide for hosting world café [Internet]. 2015 [cited 2018 Dec 20]. Available from: http://www.theworldcafe.com/wp-content/uploads/2015/07/Cafe-To-Go-Revised.pdf

5. Chang WL, Chen ST. The impact of World Café on entrepreneurial strategic planning capability. J Bus Res. 2015;68(6):1283-90. doi: 10.1016/j. jbusres.2014.11.020

6. Kimminau KS, Jernigan C, LeMaster J, Aaronson LS, Christopher M, Ahmed S, et al. Patient vs. community engagement: emerging issues. Med Care. 2018;56(10 Suppl 1):S53 S57. doi: 10.1097/MLR.0000000000000772

7. Van Assche N, Fickl S, Francisco H, Gurzawska K, Milinkovic I, Navarro JM, et al. Guidelines for development of Implant Dentistry in the next 10 years regarding innovation, education, certification, and associations. Clin Oral Implants Res. 2018;29(6):568-75. doi: 10.1111/clr.13154

8. Thompson W, Reeve E, Moriarty F, Maclure M, Turner J, Steinman M, et al. Deprescribing: Future directions for research. Res Soc Adm Pharmacy. doi: 10.1016/j.sapharm.2018.08.013

9. MacFarlane A, Galvin R, O'sullivan M, Mclnerney C, Meagher E, Burke D, et al. Participatory methods for research prioritization in primary care: an analysis of the World Café approach in Ireland and the USA. Fam Pract. 2018;34(3):278-84. doi: 10.1093/fampra/cmw104

10. Minayo MCS. Qualitative analysis: theory, steps and reliability. Cien Saude Colet. 2012;17(3):621-26. doi: 10.1590/S1413-81232012000300007 